\title{
How Does Energy Security Definition Vary Across Nations? A Review of Major Energy Consumers
}

\author{
Zhan-Ming Chen*, Yuan Chang and Yi-Ming Sun
}

\author{
School of Economics, Renmin University of China, 100872 Beijing, China
}

\begin{abstract}
The energy security issue has been paid close attention by many countries owing to the rising energy demand, the limited energy reserve, and the climate change problem. In spite of the broad concern, there is no globally accepted definition of energy security because, for any country, the impact of energy insecurity is highly correlated with its economic status, its resource endowment, its geopolitical partnership, as well as many other nation-specific features. Therefore, by using some of the world's largest energy consuming nations as examples, this article reviews the definitions of energy security and discusses the strategies to enhance it, in order to provide insight for policy makers from different countries. The results find that major energy consuming countries take measures to improve energy security status primarily by improving energy self-sufficiency and increasing energy diversification. Besides, this study also provides suggestion for different countries to take part in international energy cooperation in order to achieve a Pareto improvement of their energy security statuses.
\end{abstract}

Keywords: Energy security, energy consuming country, international energy cooperation.

\section{INTRODUCTION}

With the energy problem becoming a hot topic in the world, the issue of energy security has undoubtedly been put into an important position [1]. In spite of the broad concern, there is no globally accepted definition of energy security. One of the major reasons leading to different understanding on the concept is that, for any country, the requirements to maintain energy security as well as the impact of energy insecurity is highly correlated with its economic development status, its local energy endowment, its geopolitical relationship with other nations, and its many other nation-specific features. Therefore, the target of this review article is to clarify the different energy security definitions in the world's largest energy consuming nations, in a bid to provide insight for policy makers from different countries for possible international energy cooperation to enhance energy securities as a Pareto improvement.

Although there are disagreements on the definition of energy security, some aspects are usually included as its common features, i.e., to assure adequate, reliable, and uninterrupted supplies of energy at reasonable prices and in ways that do not jeopardize major national values and objective [2]. But different researchers or policy makers usually have different interpretations or emphasis. Some pay more attention on the economic perspective while the others stress the political and strategic sides. The former emphasizes energy efficiency and the externalities of

*Address correspondence to this author at the School of Economics, Renmin University of China, 100872 Beijing, China; Tel: +86 1082500321 ; Fax: +86 10 62511091; E-mail: chenzhanming@ruc.edu.cn, chenzhanming@pku.edu.cn power disruptions, the latter cares more about the stable supply and the affordable price. Beside the different emphasis on supply security, disagreement also occurs for the environmental issue, when some researchers and policy makers consider it as a separated dimension from energy security, most of them treat environmental effect as an essential component of energy security. They synthesize environmental concerns in energy security and target on the sustainable development which means "meets the needs of the present without compromising the ability of future generations to meet their own needs [3]". Another important factor results in the different understanding of energy security is time. In the short run, the core task of maintaining energy security is to meet the energy demand, which means continuity of physical supply. In the long run, however, the concept of energy security includes other factors such as energy infrastructure and cost minimization [4].

The concept of energy security is sometimes interpreted from the opposite direction of energy insecurity, which can be measured according to the changes of economic performance and social welfare of a country in a non-secure energy situation. Symptoms of a non-secure situation usually include sharp energy price rises, reduction in quality, sudden supply interruptions, and long-term disruptions of supply. The insecurity situation is usually resulted from either natural endowment of energy resources (scarcity or uneven geographical distribution) or supply capacity of energy infrastructure (safety transportation of energy to end users), or both.

The article starts with a detailed overview of the energy policies of major energy consuming countries 
including the United States, China, Japan, Russia, France, and the United Kingdom. This study tries to figure out what kind of strategy they use to ensure their security of energy, which will give us a better understanding of the definition.

\section{UNITED STATES}

The United States used to be the largest energy consumer as well as energy importer in the world, which relies heavily on traditional fossil energy. In $2007,85 \%$ of the energy supply for the United States is from fossil fuel, $7 \%$ is from new energy, while the remaining fraction is from nuclear power and hydro power. Since the United States' economy depends heavily on petroleum, sufficiency and steady price of petroleum are important for the energy security for the country. To guarantee sufficient and stable energy supply, the United States' government adopts the going-out strategy and focuses on overseas energy resources development. The government establishes cooperative relationship with major oil producing countries and implements varies policies to encourage oil companies to invest in oversea energy projects, in order to guarantee its energy import. At the same time, the United States carries out a lot of policies to increase energy efficiency and reduce energy consumption. In 2010, the United States' president Barrack Obama announced a new energy policy to revolutionize its energy structure in American Clean Energy and Security Act, which emphasizes on the continuous development of nuclear energy, hydropower, wind power, biomass energy, and other new energy in order to improve the energy selfsufficiency rate [5].

The recent shale gas exploitation in the United States is deemed to be a momentous event for the global energy market. As so far the only country that can conduct large-scale commercial exploitation of shale gas, the United States enhances its energy security situation by the massive supply of domestic shale gas. In additional to the shale gas, the exploitation of Canadian oil sands and the discovery of Brazil's pre-salt fields contribute to the security of energy supply for the United States. Those changes may also urge the United States' government to change its energy diplomatic policy, at least would make it more flexible in case of the policy towards Middle East countries [6]. However, owing to the nonrenewable nature of shale gas as one of the fossil energy, to solidify the foundation of energy security in the long run, the United States still needs to push the technology development, increase energy efficiency, and promote the renewable energy development.

In conclusion, the United States has recently been released from its heavy burden of energy security thanks to the exploitation of shale gas, which makes its energy independency strategy possible. It also improves the capacity of the United States to influence international energy market. In the foreseeable future, the United States will keep its new energy policy and be an important force in the global energy market.

\section{CHINA}

The most frequently adopted definition of energy security by Chinese researchers is similar to that by their United States counterparts as "adequate, affordable, and reliable supply" of energy [7]. However, researches from the two countries still have different focuses on the three dimensions of sufficiency, affordability, and reliability.

Since China's energy demand is growing much faster than its expansion of energy production, China's increasing energy consumption is heavily dependent on imported energy. However, owing to the abundant domestic coal resources, China's energy demand will be mainly satisfied by domestic production for a long time in the coming decades. Some scholars believe the major concern of the Chinese government towards its energy security is its worry about the dependence on foreign oil supply, especially on the oil producers who are politically allied with the United States [8]. As a result, the worry about stability for foreign oil supply forms a major part of China's energy security strategy [9].

Another stream of researchers conclude China's energy security problem as price fluctuations, availability, and environmental safety. The risk of price fluctuations consists of the change of import costs and the change of affordability, while the risk of availability includes supply stability and transport safety. The supply security of energy has two meanings: (a) serious shortage of supply (a shortage larger than 7\% of the import amount in the previous year) could not appear constantly; (b) there should not be a longlasting unbearable high oil price [10]. China faces various risks in the process to safeguard the availability of energy, and is lack of sufficient resistance to the volatility of oil price.

According to [11], concerning the domestic need, the basic target of energy security is to realize the 
transition from meeting the demand of the growing population to improving the service quality for everyone.

Regarding the international situation, the prior task of international energy cooperation is to ensure the stable import of oil and gas resources at acceptable prices. Since the bargaining power of China in international energy market is still not large, to expand its energy cooperation with other countries is a necessary way to protect China's energy security [12].

\section{JAPAN}

Owing to the fact that domestic natural energy resources are extremely insufficient in Japan, the core policy to enhance its energy security is "offsetting its stark scarcity of domestic resources through diversification, trade, and investment", or more specifically "to develop a steady supply of foreign sources of energy and to ensure a healthy energy structure-the perfect balance of energy and technology" $[7,13]$.

Japan's energy security strategy can be concluded into three points. The first one is to improve the diversification of energy sources by developing new energy. Japan's energy policy has evolved from the "coal priority" policy to heavy dependency on oil, and then emphasis on the development of alternative energy and new energy including wind, biomass, hydro, hydrogen, geothermal energy, and especially solar and nuclear energy. As a result of the new energy development policy, Japan has achieved a diversified energy sources structure to avoid threats from the supply interruption of any single energy.

The second energy security strategy for Japan is to improve energy diversification by international cooperation. As the country depends heavily on energy import $(99.7 \%$ of its oil supply, $97.7 \%$ of its coal supply, and $96.6 \%$ of its gas supply were imported in 2012 [14]), a stable international energy market is very important for the energy security of Japan. Since the 1990s, Japan made efforts to diversify the import sources of oil, till now it imports oil from 40 countries or regions. The recent emphases of this strategy include adjusting the import amount from the Middle East, getting oil from Russia, getting oil and gas from Africa, and expanding import from the Central Asia region.

And the last strategy is energy conservation. As an island country, Japan is facing the serious situation of energy shortage. "Too expensive to be waste" is the credo of energy conservation for all Japanese. Therefore, improving energy efficiency is a major measure for Japan to improve its energy security. During the recent years, Japan has made dramatic progress in improving its energy efficiency, and in the meanwhile has committed to the implementation of energy-saving technology in the other Asian countries.

It is worthy to emphasize the development of nuclear energy in Japan. Japan started using nuclear energy since 1960s, till 2011 there are already 55 nuclear power reactors, which produce $30 \%$ of the national total electricity supply [15]. Since the explosion of the Fukushima Daiichi nuclear power plant in March 2011, the safety of nuclear power usage is becoming a more and more important aspect for Japan's energy security. However, even though the nuclear power generation was reduced by over $90 \%$ in 2012 comparing to 2010 as a result of the explosion, the domestic electricity supply was reduced by less than $10 \%$ owing to its diversified sources of electricity generation.

\section{RUSSIA}

As the world's largest gas exporter and the second largest oil exporter, Russia pays special attention to the security of energy demand, i.e., how to maintain a strong and stable international energy demand at a reasonable price, in order to maximize its national economic benefits. Therefore, maintaining reliable trade with multiple buyers with stable energy demand in the complicated international energy market becomes the main principle of Russia's energy security strategy.

Energy export has always been a major source of foreign exchange revenue for Russia. At the same time, energy industry makes a significant contribution to the national economy. However, the heavy dependency on energy industry also causes problems for its energy security. The energy insecurity of Russia can be attributed to domestic and foreign challenges. Regarding the domestic side, there is large investment gap in Russia's oil and gas industry, causing problem in maintaining and updating the infrastructure of energy industry [16]. Besides, the costs of oil exploitation and transportation are much higher than those of the other major oil exporters, which weakens the competitiveness of Russia in international oil market [17]. The institutional factor is another domestic factor threatening Russia's energy security. The Russian 
government has very limited influence on private investment in the oil industry. On the contrary, however, strengthen the control of oil sector and oil market may result in reduced efficiency of the oil industry. Therefore, the Russian energy security is defined as "restrictions on foreign investment in the field of oil and gas in the whole country" [18]. The last domestic challenge is the necessity to improve the relatively low energy efficiency.

For the foreign side, the most important challenge is the price volatility of international energy market. There is a clear correlation between the GDP growth rate of Russia and international oil prices, as a result of the fact that Russia's economy is heavily dependent on its energy industry. Therefore, the fluctuations in international oil market will directly affect Russia's government revenues, and thus have significant impact on the national economy. Geopolitical factor also has significant impacts on Russia's energy security. In order to make full use of its oil and gas resources in foreign relations, Russia is trying to diversify its export structure. Following this energy strategy, Russia is to enhance its traditional cooperative links with European countries on the one hand and establish new cooperation with the Asia-Pacific countries on the other hand. Particularly, the trivial situation of trilateral trade between Russia, the United States, and China creates both opportunities and challenges for the three countries regarding their economic and energy strategies. Thus, energy diplomacy is an important component of Russia's energy security policy.

According to [19], the energy security of Russia refers to the state to protect the security of its citizens, society, nation, and economy from all kinds of threats by providing a reliable supply of energy. The threats mainly come from the insecurity of geopolitical relationship, macroeconomic situation, international energy market, and the general status of domestic energy industry. The Russian government is making efforts from all aspects to address the threats. In 2003, the Russian government formally promulgated the "Russian Energy Strategy by 2020", which elaborated guidelines for Russian energy security [19]. Overall, to develop a diversified and stable foreign market by using energy diplomacy, to enhance the ability to safeguard major position and market forces of energy export, and to develop more extensive international cooperation around the world are main topics of Russia's energy security strategy.

\section{FRANCE}

France has three principles to ensure its energy security. The first one is to guarantee security by relying on self supply. Self-sufficiency reduces the threat of unaffordable price and sudden import interruption, which may possibly be introduced by oil exporting country's political turbulent. Self-sufficiency can also avoid many losses in the process of international transportation e.g. the risk of pirate. The secure and continuous support can keep satisfying the energy demand of the country, thus contributes to its economy development. The second principle is to stimulate new energy development, which can increase domestic energy supply and mitigate carbon emissions at the same time. In 2005, a new law came into effect to allow companies using renewable energy to have $40 \%$ of tax exemption, and the percentage has been increased to $50 \%$ since 2006 . There are also other supportive policies to encourage renewable energy development, e.g., grid companies have the obligation to buy all the electricity generated from renewable sources, especially from wind power generators. The third principle is to encourage technological progress, recognizing the point that energy supply security depends heavily on technical support.

France is the largest net electricity exporter in the world, which is attributed to the high percent of nuclear power in its energy supply structure. Its nuclear development dates back to the oil shocks in the 1970s, when the French government came to realize that its energy supply is threatened by the lack of fossil fuel and the sustaining rising of oil price. Consequently, developing reliable and sufficient new energy like nuclear became a priority task to enhance energy security in France. The nuclear power generation increased sharply from 18.0 TWh in 1977 to $30.5 \mathrm{TWh}$ in 1978 (see Figure 1, data from [20]). Until 2012, the total power generation is $555.1 \mathrm{TWh}$, while nuclear power generation contributes to $76.6 \%$ of it [20]. At the same time, the power generation from hydro and other renewable sources exceeds that from fossil energy, which also contributes to the self-sufficiency of France's energy supply.

Even though the anti-nuclear voice becomes louder after the Fukushima nuclear accident, the French government insists on its nuclear power development strategy to ensure its energy security. With that regard, secure technical guarantee is of vital importance [21]. There is a saying that the relative risk is always compared with other risk or economic benefits that 


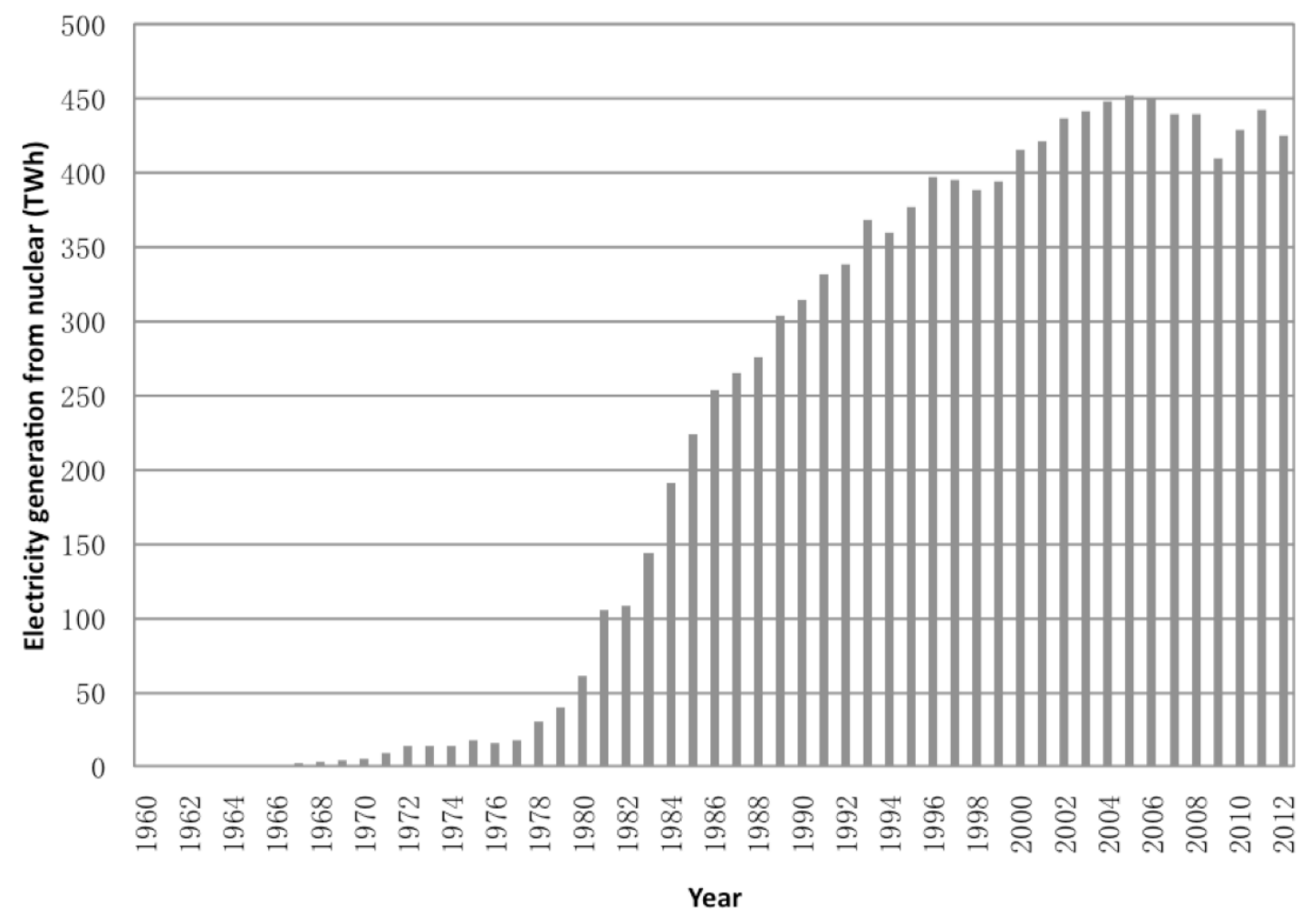

Figure 1: Electricity generation from nuclear in France, 1960-2012.

earned under the risk [22]. The risk of not using nuclear energy is related to climate changes, supply disruption, and economic benefit. Different countries will confront different degree of risks and thus have different attitudes toward nuclear energy usage according to their respective natural and social conditions. For France, with the technical progress the threat of nuclear accident is inappreciable comparing with its energy security problem, which makes nuclear power a priority choice to ensure its energy security by now.

\section{UNITED KINGDOM}

Comparing to the other European countries, the United Kingdom has both abundant and diversified energy resources such as coal, oil, natural gas, nuclear power, and hydro power. To conserve natural energy resources and to response to the appeal for low carbon transition, the British government focuses on energy diversification, energy efficiency increase, and competitive energy price as the major principles to ensure its energy security. Besides, the United Kingdom also takes an active part in low-carbon development to cope with the climate change issues along with the realization of energy supply security.

The United Kingdom is very positive to exploit its rich marine resources, from offshore oil to tidal power, wind power, and the other new energy. With the world's leading energy technology, the British government keeps increasing spending on renewable energy development and plays a positive role in international energy cooperation. In 2012, hydro power production contributes to $2 \%$ of the total electricity generation. Meanwhile, to diversify the use of energy, the British government is very active to support new energy development by both on policy and finance measures. The government launched a "renewable energy obligation" which requires all electricity suppliers to produce a certain percentage of its electricity from renewable sources, which can be used as a tradable permit between the suppliers with additional renewable energy capacity and those without sufficient capacity. Another policy is to levy additional tax on companies with large energy consumption to subsidy on those using bio-energy, in this way to adjust the energy market by price. Nuclear energy is also an important energy source for the United Kingdom, which contributes to nearly $20 \%$ of the total energy supply in 2012. The usage of nuclear energy is generally recognized as an appropriate way to ensure the energy supply and reduce carbon dioxide emissions by the United Kingdom citizens.

Presented in Figure 2 is the energy source structure of the United Kingdom's electricity generation in 2012 [23], according to which coal is still the prominent 


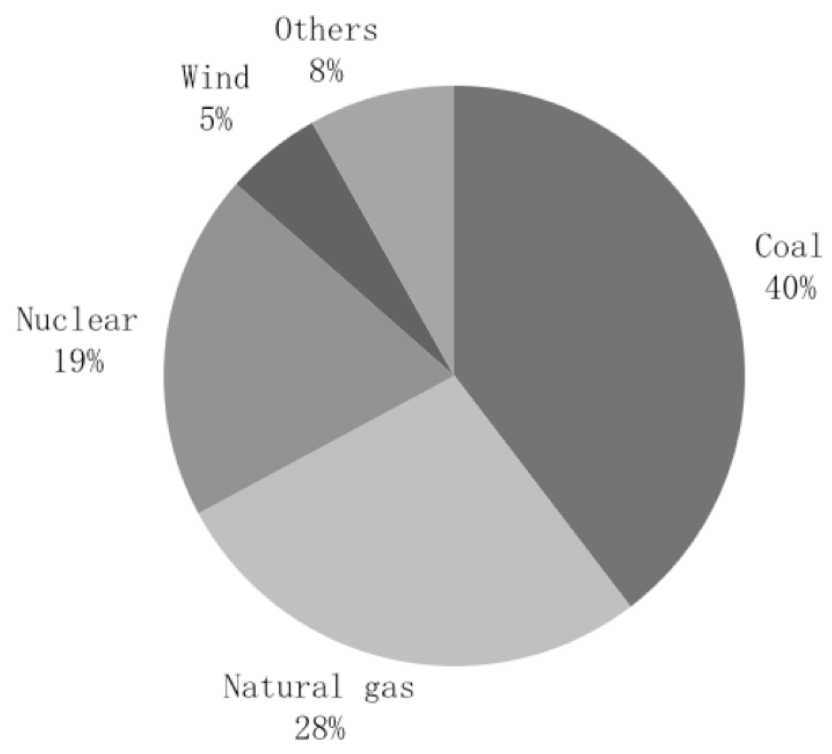

Figure 2: Energy source structure of the United Kingdom's electricity generation in 2012 .

energy source. In order to mitigate carbon emissions to cope with the global climate change issue, the British government is very active to promote the carbon capture and storage (CCS) technology. A series of activities such as CCS demonstration projects have been conducted in the United Kingdom. As the world's largest coal consumer, China has been considered as one of the important factors in the United Kingdom's decision on how to promote CCS technology roadmap and how to promote international cooperation. In this circumstance, there is a possibility for the cooperation between the United Kingdom and China to accelerate and expand the commercial deployment of CCS technology, which is a win-win strategy which can incite the economic development and reduce carbon dioxide emissions for both countries. To sum up, the most important strategy the United Kingdom to ensure its energy security is to keep the energy sources diversified, which reduces the risk of supply interrupt of a single energy source.

\section{CONCLUSION}

Energy security can be divided into security of supply, security of demand, and security of transportation, while the focus varies from country to country. The resource endowment situation and the developing goal differ from country to country, so accordingly, policy makers put emphasis on different aspects of energy security. The United States pushes shale gas revolution and going-out strategy to guarantee adequate and stable supply; China tries to meet the need for increasing energy demand in both domestic and foreign strategy as well as to confront the deteriorating environmental problem; Japan continues to make high efficient use of energy to maintain the perfect balance of energy and technology; Russia makes effort to safeguard stable buyers by using energy diplomacy and extensive cooperation; France develops new energy to ensure self-sufficiency; the United Kingdom promotes energy diversification and CCS technology. To sum up, they make strategies according to their different resource endowments to maximize their national interests. Moreover, enhancing the international cooperation is considered to be a good method to realize a win-win result. When England promoting its CCS technology cooperation with China, which will help promote its roadmap and add its economic benefit, China will also gain the opportunity of reducing environmental problems. In additional to the technical aspect of international cooperation, countries can also strengthen the cooperation in the exploitation of energy, environmental conservation, and development of new energy. Meanwhile, developing international dialogue and consultation in political field is also a main choice among those countries.

In conclusion, we need to see the energy security problem comprehensively, knowing the content and analyzing the nation's resource endowment. Developing international cooperation to accelerate the enhancement of energy security, which is an ideal way to realize Pareto improvement.

\section{ACKNOWLEDGEMENTS}

This research has been supported by the Fundamental Research Funds for the Central Universities, and the Research Funds of Renmin University of China (Grant No. 14XNJ011).

\section{REFERENCES}

[1] Lesbirel SH. Diversification and energy security risks: the Japanese case. Japanese J Pol Sci 2004; 5: 1-22. http://dx.doi.org/10.1017/S146810990400129X

[2] Andrews CJ. Energy security as a rationale for governmental action. Technology and Society Magazine, IEEE 2005; 24 $16-25$ http://dx.doi.org/10.1109/MTAS.2005.1442377

[3] Intharak N, Julay J H, Nakanishi S, et al. A Quest for Energy Security in the 21st Century. Asia Pacific Energy Research Centre Report, 2007.

[4] Creti A, Fabra N. Supply security and short-run capacity markets for electricity. Energy Economics 2007; 29: 259-76. http://dx.doi.org/10.1016/i.eneco.2006.04.007

[5] $\mathrm{Hu} Y$. The new energy policy of Obama government and the energy safety of our country. Ecological Economy 2010; 7 : $32-4$ 
[6] Chen $\mathrm{H}$. Share gas revolution and the energy independence of North America and the inspiration of China. Natural Gas Technol Economy 2013; 5.

[7] Downs E. Energy Security Series. The Brookings Foreign Policy Studies, 2006.

[8] Kennedy AB. China's new energy security debate. Survival 2010; 52: 137-58. http://dx.doi.org/10.1080/00396338.2010.494881

[9] Downs ES, Mesic R, Charles Jr T, et al. China's quest for energy security. Rand Corporation, 2000.

[10] Zhang Y, Guan Q. The pattern of global energy and China's energy security. World Economy 2007; 9: 17-30.

[11] Cai G, Zhang L. The researching progress of China's energy security. Progress in Geography 2005; 24: 79-87.

[12] Guan Q, He F. China's energy security and energy international cooperation. World Economics and Politics 2008: 45-53.

[13] Yergin D. Ensuring energy security. Foreign affairs 2006: 6982. http://dx.doi.org/10.2307/20031912

[14] Feng Z. International Energy Pattern in 21 Century and Future Long-term Change - the solution of Japan's energy security. International Security Studies CSSCI, 2013.

[15] Tian S. The dependence on nuclear power and law policy in Japanese lowcarbon society. Tsinghua Law Journal 2011; 3: 016.
[16] Yuan X, Zhang J. The analysis of the restriction in Russian energy strategy and diplomacy. The Journal of Shanghai Administration Institute 2006; 7: 62-73.

[17] Wei J. Russian's energy security agenda outlook. World Outlook 2013; 3: 108-231.

[18] Levin Institute. The evolving concept of energy security. http://www.globalization101.org/the-evolving-concept-ofenergy-security/, accessed on 20th, May, 2013.

[19] Li H. The Research of Russian Energy Security Strategy. Haerbin: Heilongjiang University, 2008.

[20] World Bank. World Development Indicators. http://databank.worldbank.org/data/views/variableselection/s electvariables.aspx?source=world-development-indicators, accessed on 20th, May, 2015.

[21] Han X, Zhang Q. The energy situation and development policy of France. Global Science Technology and Economy Outlook 1998; 12: 007.

[22] Teräväinen T. Political opportunities and storylines in Finnish climate policy negotiations. Environmental Politics 2010; 19: 196-216. http://dx.doi.org/10.1080/09644010903574475

[23] IEA. United Kingdom: Electricity and Heat. http://www.iea.org/statistics/statisticssearch/report/?year=201 $2 \&$ country=UK\&product=ElectricityandHeat, accessed on 20th, May, 2015. 